\title{
Locally Advanced Skin Squamous Cell Carcinoma
}

National Cancer Institute

\section{Source}

National Cancer Institute. Locally Advanced Skin Squamous Cell Carcinoma. NCI

Thesaurus. Code C153182.

A squamous cell carcinoma of the skin that has spread from its original site of growth to nearby tissues or lymph nodes. 